\title{
KONSEPTUALISASI TEORI MASLAHAH $H^{*}$
}

\author{
Asmawi ${ }^{1}$ \\ Permalink: https://www.academia.edu/9998895
}

\begin{abstract}
Conceptualization of Benefits Theory. The foundation of Islamic shariah is represented by benefits which aim to the importance of people as human being, both for benefit in life and after life. Islamic shariah upholds justice principals, affections and benefits. Every law which against those principals is not considered as a part of Islamic shariah; even though many people are searching its rationalization to include it as Islamic law. The greatness and the nobleness of Islamic shariah are implemented through the compatibility of those shariah laws into human real life due to benefits theory human possesses.
\end{abstract}

Keywords: Benefits, shariah

Abstrak: Konseptualisasi Teori Maslahah. Fondasi bangunan Syariah Islam itu direpresentasikan oleh maslahah yang ditujukan bagi kepentingan hidup manusia sebagai hamba Allah, baik menyangkut kehidupan duniawinya maupun kehidupan ukhrawi-nya. Syariah Islam itu menjunjung tinggi prinsip-prinsip keadilan ('adâlah), kasih sayang (rahmah), dan maslahah,. Setiap aturan hukum yang menyimpang dari prinsip-prinsip tersebut pada hakikatnya bukanlah bagian dari Syariah Islam, meskipun dicari rasionalisasi ( $t a{ }^{\prime}$ wîl) untuk menjadikannya sebagai bagian dari Syariah Islam. Keagungan dan keluhuran Syariah Islam termanifestasikan pada kompatibilitas hukum-hukum Syariah dengan perkembangan kehidupan manusia lantaran ruh maslahah yang menggerakkannya.

Kata Kunci: Maslahah, Syariah

* Diterima tanggal naskah diterima: 10 November 2014, direvisi: 20 November 2014, disetujui untuk terbit: 22 November 2014.

${ }^{1}$ Fakultas Syariah dan Hukum UIN Jakarta, Jl. Ir. H. Juanda No.9 Ciputat. E-mail: asmawi99@gmail.com. 


\section{Pendahuluan}

Tulisan ini akan membicarakan isu pokok reformulasi teori maslahah, yang meliputi sub-bahasan (i) kualifikasi dan eksistensi maslahah, (ii) kategorisasi maslahaha, dan (iii) relasi maslahah dengan nass Syara'.

Dalam kajian teori hukum Islam (ușull al-fiqh), maslahahah diidentifikasi dengan sebutan (atribut) yang bervariasi, yakni prinsip (principle, al-asl, alqấidah, al-mabda') ${ }^{2}$, sumber atau dalil hukum (source, al-masdar, al-dalî̀ $)^{3}$, doktrin (doctrine, al-d̂âbit $)^{4}$, konsep (concept, al-fikrah) ${ }^{5}$, metode (method, altarîqah $)^{6}$, dan teori (theory, al-nazariyyah) ${ }^{7}$.

Patut diketahui bahwa teori maslahah dikonseptualisasi oleh para ulama ahli usûul sepanjang sejarah hukum Islam. Tentu saja terdapat dinamika pemikiran dalam rangka konseptualisasi tersebut. Uraian berikut ini

${ }^{2}$ Identifikasi maslahat sebagai sumber atau dalil (masdar, al-dalî́) ditunjukkan dalam, misalnya , 'Abd al-Wahhâb Khallâf, Maŝâdir al-Tasyrî̀' al-Islâmiy fîmâ lâ Nass fîh, (Kuwait: Dâr al-Qalam, 1392 H/1972 M). Lihat juga Zakariyya al-Birri, Masâdir al-Ahkâm al-Islâmiyyah, (Kairo: Dâr al-Ittihâd al-'Arabiy, 1395 H/1975 M); dan Mustafa Dîb al-Bugâ, Atsar al-Adillah alMukhtalaf fîhâ au Masâdir al-Tasyrî̀ al-Taba iyyah fi al-Fiqh al-Islâmiy, (Damaskus: Dâr alImâm al-Bukhâri, t.th.); dan Wahbah al-Zuhaili, Usûl al-Fiqh al-Islâmiy, (Beirut: Dâr al-Fikr, 1406 H/1986 M); dan 'Ali Hasaballah, Us sûl al-Tasyrî̀' al-Islâmiy, (Mesir: Dâr al-Ma'ârif, 1383 H/1964 M), hlm. 107; dan Ahmed Hassan, The Early Development of Islamic Jurisprudence, (New Delhi: Adam Publishers \& Distributors, 1994), hlm. 53; 'Abdullah 'Abd al-Muhsin alTurki, Asbâb Ikhtilâf al-Fuqaha', (Riyad: Maktabah al-Riyâd al-Hadîtsah, 1397 H/1977 M); dan Mustafa Zaid, al-Maslaḩah fi al-Tasyrî́ al-Islâmiy wa Najm al-Dîn al-Tûfi, (Kairo: Dâr al-Fikr al'Arabiy, 1384 H/1964 M); dan Muslih 'Abd al-Hayy al-Najjâr, al-Adillah al-Mukhtalaf fîhâ 'ind al-Usû́liyyîn wa Tatbîqâtuhâ al-Mu âsisirah, (Riyad: Maktabah al-Rusyd, $1424 \mathrm{H}$ );

Identifikasi maslahat sebagai prinsip (principle, al-asl, al-qấidah, al-mabda') ditunjukkan dalam, misalnya, Jalâl al-Dîn 'Abd al-Rahmân, al-Masâlih al-Mursalah wa Makânatuhâ fi al-Tasyrî‘ al-Islâmiy, (Kairo: Dâr al-Kitâb al-Jâmi'iy, 1403 H/1983 M), hlm. 16; dan Hamâdi al-'Ubaidi, Ibn Rusyd wa 'Ulûm al-Syarî‘ah al-Islâmiyyah, (Beirut: Dâr al-Fikr al'Arabiy, 1991), h. 96.

${ }^{4}$ Identifikasi maslahat sebagai doktrin (doctrine, al- $\underline{\text { dâbit }}$ ) ditunjukkan dalam, misalnya, Muhammad Sa'îd Ramadân al-Bûtí, Dawâbit al-Maślahah fi al-Syarî́ah al-Islâmiyyah, (Beirut: Mu'assasat al-Risâlah, $1421 \mathrm{H} / 2000 \mathrm{M}$ ). Lihat juga Mashood A. Baderin, International Human Rights and Islamic Law, (New York: Oxford University Press, 2003), h. 40-47.

${ }^{5}$ Identifikasi maslahat sebagai konsep (concept, al-fikrah) ditunjukkan dalam, misalnya,

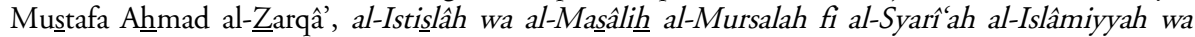
Usû́l Fiqhiha, (Damaskus: Dâr al-Qalam, 1408 H/1988 M). Lihat juga Felicitas Opwis, "Maslaha in Contemporary Islamic Legal Theory", dalam Journal Islamic Law and Society, Vol. 2, No. 12, 2005, Koninklijke Brill NV, Leiden, 2005).

${ }^{6}$ Identifikasi maslahat sebagai metode (method, al-tarîqah) ditunjukkan dalam, misalnya, Muhammad Abû Zahrah, Usû́l al-Fiqh, (Beirut: Dâr al-Fikr al-'Arabiy, t.th.), h.115. Lihat juga Tâhẩ Jâbir al-'Alwânî, Source Methodology in Islamic Jurisprudence (Usûul al-Fiqh al-Islâmîy), (Virginia: IIIT, 1415 H/1994), h.12-14; dan 'Ali al-Khafîf, Asbâb Ikhtilâf al-Fuqahâ', (Kairo: Dâr al-Fikr al-'Arabiy, 1416 M/1996), h.176; dan Mohammad Hashim Kamali, An Introduction to Sharî‘ah, (Kuala Lumpur: ILMIAH Publishers, 2006), h.119-125; dan Sâlih ibn 'Abd al-'Azîz Âli Manșûr, Usûul al-Fiqh wa Ibn Taimiyyah, (Mesir: Dâr al-Našr, 1405 H/1985 M), h.465.

Identifikasi maslahat sebagai (theory, al-nazariyyah) ditunjukkan dalam, misalnya, Husain Hâmid Hissân, Nazariyyat al-Maślahah fi al-Fiquh al-Islâmiy, (Beirut: Dâr al-Nahdah al'Arabiyyah, 1971); dan Muhammad Kamâl al-Dîn Imâm, Nazariyyat al-Fiqh fi al-Islâm: Madkhal Manhajiy, (Beirut: al-Mu'assasah al-Jâmi'iyyah li al-Dirâsât wa al-Nasyr wa al-Tauzî‘, $1418 \mathrm{H} / 1998 \mathrm{M})$. 
mendiskusikan perihal konseptualisasi teori maslahah yang terpancar dari pemikiran-pemikiran brilian para ulama itu, termasuk ulama ahli usû́l pada abad kontemporer ini.

\section{Kualifikasi dan Eksistensi Maslahah}

Dalam kajian teori hukum Islam (usûl al-fiqh), maslahahah diidentifikasi dengan sebutan (atribut) yang bervariasi, yakni prinsip (principle, al-asl, al-

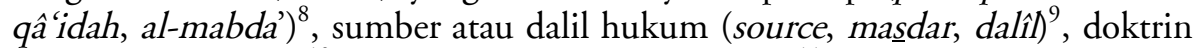
(doctrine, al-dâbit $)^{10}$, konsep (concept, al-fikrah) $)^{11}$, metode (method, altarîqah) ${ }^{12}$, dan teori (theory, al-nazariyyah $)^{13}$.

${ }^{8}$ Identifikasi maslahah sebagai sumber atau dalil (masdar, dalîl) ditunjukkan dalam, misalnya , 'Abd al-Wahhâb Khallâf, Masâdir al-Tasyrî̀ al-Islâmiy fîmâ lâ Nass fîh, (Kuwait: Dâr al-Qalam, 1392 H/1972 M). Lihat juga Zakariyya al-Birri, Masâdir al-Ahkâm al-Islâmiyyah, (Kairo: Dâr al-Ittihhâd al-'Arabiy, 1395 H/1975 M); dan Mustafa Dîb al-Bugâ, Atsar al-Adillah alMukhtalaf fîhâ au Masâdir al-Tasyrî̀ al-Taba iyyah fi al-Fiqh al-Islâmiy, (Damaskus: Dâr alImâm al-Bukhâri, t.th.); dan Wahbah al-Zuhaili, Usûl al-Fiqh al-Islâmiy, (Beirut: Dâr al-Fikr, 1406 H/1986 M); dan 'Ali Hasaballah, Usûl al-Tasyrî́ al-Islâmiy, (Mesir: Dâr al-Ma ârif, 1383 H/1964 M), hlm. 107; dan Ahmed Hassan, The Early Development of Islamic Jurisprudence, (New Delhi: Adam Publishers \& Distributors, 1994), h.53; 'Abdullah 'Abd al-Muhsin al-Turki, Asbâb Ikhtilâf al-Fuqaha', (Riyad: Maktabah al-Riyâd al-Hadîtsah, 1397 H/1977 M); dan Mustafa Zaid, al-Maslahah fi al-Tasyrî‘ al-Islâmiy wa Najm al-Dîn al-Tûfi, (Kairo: Dâr al-Fikr al-

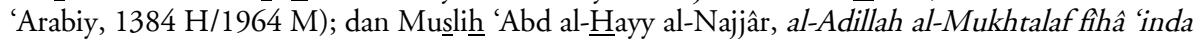
al-Usûllyyîn wa Tatbîqâtuhâ al-Mu âsisirah, (Riyad: Maktabah al-Rusyd, $1424 \mathrm{H}$ );

9 Identifikasi maslahah sebagai prinsip (principle, al-aśl, al-qấidah, al-mabda') ditunjukkan dalam, misalnya, Jalâl al-Dîn 'Abd al-Raḩmân, al-Masâalih al-Mursalah wa Makânatuhâ fi al-Tasyrî‘ al-Islâmiy, (Kairo: Dâr al-Kitâb al-Jâmi'iy, 1403 H/1983 M), h.16; dan Hamâdi al-'Ubaidi, Ibn Rusyd wa 'Ulûm al-Syarî‘ah al-Islâmiyyah, (Beirut: Dâr al-Fikr al'Arabiy, 1991), h.96.

${ }^{10}$ Identifikasi maslahah sebagai doktrin (doctrine, al-dâbiț) ditunjukkan dalam, misalnya, Muhammad Sa îd Ramadân al-Bûtí, Dawâbit al-Mas lahah fi al-Syarî́ah al-Islâmiyyah, (Beirut: Mu'assasat al-Risâlah, $1421 \mathrm{H} / 2000 \mathrm{M}$ ). Lihat juga Mashood A. Baderin, International Human Rights and Islamic Law, (New York: Oxford University Press, 2003), h.40-47.

${ }^{11}$ Identifikasi maslahahah sebagai konsep (concept, al-fikrah) ditunjukkan dalam, misalnya, Mustafa Aḥmad al-Zararầ, al-Istislâh wa al-Masâlih al-Mursalah fi al-Syarî́ah al-Islâmiyyah wa Usûl Fiqhiha, (Damaskus: Dâr al-Qalam, 1408 H/1988 M). Lihat juga Felicitas Opwis, "Maslaha in Contemporary Islamic Legal Theory", dalam Journal Islamic Law and Society, Vol. 2, No. 12, 2005, Koninklijke Brill NV, Leiden, 2005).

12 Identifikasi maślahah sebagai metode (method, al-tarîqah) ditunjukkan dalam, misalnya, Muhammad Abû Zahrah, Usûl al-Fiqh, (Beirut: Dâr al-Fikr al-'Arabiy, t.th.), h.115. Lihat juga Tâhâ Jâbir al-'Alwânî, Source Methodology in Islamic Jurisprudence (Usîll al-Fiqh alIslâmî), (Virginia: IIIT, 1415 H/1994), h.12-14; dan 'Ali al-Khafif, Asbâb Ikhtilâf al-Fuqahâ', (Kairo: Dâr al-Fikr al-'Arabiy, 1416 M/1996), h.176; dan Mohammad Hashim Kamali, An Introduction to Sharî‘ah, (Kuala Lumpur: ILMIAH Publishers, 2006), h.119-125; dan Sâlih ibn 'Abd al-'Azîz Âli Mansûr, Usûll al-Fiqh wa Ibn Taimiyyah, (Mesir: Dâr al-Našr, 1405 H/1985 M), h.465.

${ }^{13}$ Identifikasi maslahah sebagai (theory, al-nazariyyah) ditunjukkan dalam, misalnya, Husain Hâmid Hissân, Nazariyyat al-Maślahah fi al-Fiquh al-Islâmiy, (Beirut: Dâr al-Nahdah al'Arabiyyah, 1971); dan Muhammad Kamâl al-Dîn Imâm, Nazariyyat al-Fiqh fi al-Islâm: Madkhal Manhajiy, (Beirut: al-Mu'assasah al-Jâmi iyyah li al-Dirâsât wa al-Nasyr wa al-Tauzî‘, $1418 \mathrm{H} / 1998 \mathrm{M})$. 
Secara etimologis, arti al-masla $\underline{h a h}$ dapat berarti kebaikan, kebermanfaatan, kepantasan, kelayakan, keselarasan, kepatutan. Kata almaslahah dilawankan dengan kata al-mafsadah yang artinya kerusakan. ${ }^{14}$

Secara terminologis, maslahah telah diberi muatan makna oleh beberapa ulama usûul al-fiqh. Al-Gazâli (w. $505 \mathrm{H}$ ), misalnya, mengatakan bahwa makna genuine dari maslahah adalah menarik/mewujudkan kemanfaatan atau menyingkirkan/menghindari kemudaratan (jalb manfa'ah atau daf madarrah) Menurut al-Gazâli, yang dimaksud maslahah, dalam arti terminologis-syar'i, adalah memelihara dan mewujudkan tujuan Syara' yang berupa memelihara agama, jiwa, akal budi, keturunan, dan harta kekayaan. Ditegaskan oleh al-Gazâli bahwa setiap sesuatu yang dapat menjamin dan melindungi eksistensi kelima hal tersebut dikualifikasi sebagai masslahah; sebaliknya, setiap sesuatu yang dapat mengganggu dan merusak kelima hal tersebut dinilai sebagai mafsadah; maka, mencegah dan menghilangkan sesuatu yang demikian dikualifikasi sebagai maslahah. ${ }^{15}$

Pengertian maslahah juga dikemukakan oleh 'Izz al-Dîn 'Abd al-Salâm (w. $660 \mathrm{H})$. Dalam pandangan 'Izz al-Dîn 'Abd al-Salâm, maślahaha itu identik dengan al-khair (kebajikan), al-naf(kebermanfaatan), al-h̆usn (kebaikan). ${ }^{16}$ Sementara Najm al-Dîn al-Tûfi (w. $716 \mathrm{H}$ ) berpendapat bahwa makna maslahah dapat ditinjau dari segi 'urfi dan syar'i. Menurut al-Tûfi, dalam arti 'urfi, maslahah adalah sebab yang membawa kepada kebaikan dan kemanfaatan, seperti perniagaan yang merupakan sebab yang membawa kepada keuntungan, sedang dalam arti syar'i, masslahah adalah sebab yang membawa kepada tujuan al-Syârí, baik yang menyangkut ibadah maupun muamalah. ${ }^{1 \dagger}$ Tegasnya, mas lahah masuk dalam cakupan maqâsid al-syarî́ah. ${ }^{18}$

Syariah Islam compatible bagi segala kebutuhan dan tuntutan kehidupan manusia. Teks-teks Syariah (nușûs al-syarî́ah) dapat mewujudkan-

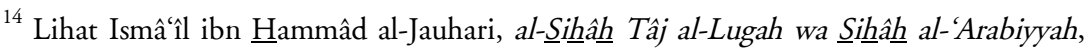
(Beirut: Dâr al-'Ilm li al-Malâyîn, 1376 H/1956 M), Juz ke-1, h.383-384; dan Abû al-Husain Ahmad ibn Fâris ibn Zakariyyâ, Mu jam Maqâyîs al-Lugah, (Kairo: Maktabah al-Khânjî,, 1403 H/1981 M), Juz ke-3, h.303; dan Jamâl al-Dîn Muhammad ibn Mukarram ibn Manzûr al-Ifrîqi, Lisân al-'Arab, (Riyad: Dâr 'Âlam al-Kutub, 1424 H/2003 M), Juz ke-2, h.348; dan Muhammad ibn Abi Bakr ibn 'Abd al-Qâdir al-Râzi, Mukhtâr al-Sihhâh, (Beirut: Dâr al-Kitâb al-'Arabi, 1979), h.376; dan Muhammad ibn Abi Bakr ibn 'Abd al-Qâdir al-Râzi, Mukhtâr al-Sịhâh al-Kitâb al-'Arabi, 1979), h.376; dan Muhammad Murtadâ al-Husaini al-Zabî̀î̀, Tâj al-'Arûs min Jawâhir al-Qâmûs, (Beirut: Dâr al-Fikr, 1414 H/1994 M), Juz ke-4, h.125-126; dan Ibrâhîm Mustafa, dkk., al-Mu jam al-Wasît , (Tahrân: al-Maktabah al-'Ilmiyyah, t.th.), Juz ke-1, h.522.

${ }^{15}$ Abû Hâmid Muhammad al-Gazâli (selanjutnya disebut al-Gazâli), al-Mustaśfa min 'Ilm al-Usû́l, tah̆qî̀q wa ta'lî̀q Muhammad Sulaimân al-Asyqar, (Beirut: Mu'assasat al-Risâlah, 1417 H/1997 M), Juz ke-1, h.416-417.

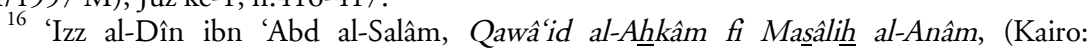
Maktabat al-Kulliyyât al-Azhariyyah, 1994), Juz ke-1, h.5.

${ }^{17}$ Najm al-Dîn al-Tûfi, Syarh al-Arba în al-Nawawiyyah, h.19, lampiran dalam Mustafa Zaid, al-Maślahah fi al-Tasyrî̀ al-Islâmiy wa Najm al-Dîn al-Thûfi, t.tp.: Dâr al-Fikr al-'Arabiy, $1384 \mathrm{H} / 1964 \mathrm{M})$, h.211.

${ }^{18}$ Hamâdi al-'Ubaidi, Ibn Rusyd wa 'Ulûm al-Syarî‘ah al-Islâmiyyah, (Beirut: Dâr alFikr al-'Arabiy, 1991), h.97. 
bagi manusia-maslahah pada setiap ketentuan hukumnya. Tidak ada satu pun masalah hukum yang muncul kecuali sudah ada-di dalam Kitab Allah-petunjuk jalan solusi atasnya. ${ }^{99}$ Syariah Islam merupakan syariah yang selaras dengan fitrah kemanusiaan (syarî́at al-fitrah), yang memperhatikan segenap sisi kehidupan manusia, dan yang menawarkan tuntunan hidup yang berkeadilan. Syariah Islam juga merupakan syariah yang selaras dengan moralitas kemanusiaan yang luhur, yang membebaskan manusia dari cengkeraman kuasa hawa nafsu yang destruktif. Syariah Islam merupakan syariah yang bervisi dan bermisi mulia. ${ }^{20}$ Syariah Islam senantiasa memperhatikan realisasi maslahhah bagi segenap hamba-Nya. Karena itulah, konsep maslahah memberi saham besar bagi terwujudnya panduan yang layak diperhatikan sang mujtahid guna mengetahui hukum Allah atas perkara yang tidak ditegaskan oleh nass Syara'. ${ }^{21}$ Jelaslah bahwa maslahah menjadi elan vital bagi Syariah Islam sehingga ia senantiasa memiliki relevansi dengan konteks zamannya; dan ini pada gilirannya menjadikan Syariah Islam tetap up to date menyapa segenap persoalan kehidupan manusia dengan cahaya ajarannya yang mencerahkan.

Fondasi bangunan Syariah Islam itu direpresentasikan oleh maslahah yang ditujukan bagi kepentingan hidup manusia sebagai hamba Allah, baik menyangkut kehidupan duniawinya maupun kehidupan ukhrawi-nya. Syariah Islam itu menjunjung tinggi prinsip-prinsip keadilan ('adâlah), kasih sayang (rahmah), dan maslahah,. Setiap aturan hukum yang menyimpang dari prinsipprinsip tersebut pada hakikatnya bukanlah bagian dari Syariah Islam, meskipun dicari rasionalisasi ( $\left.\operatorname{ta}^{\prime} w \hat{l} l\right)$ untuk menjadikannya sebagai bagian dari Syariah Islam. $^{22}$ Keagungan dan keluhuran Syariah Islam termanifestasikan pada kompatibilitas hukum-hukum Syariah dengan perkembangan kehidupan manusia lantaran ruh maslahah yang menggerakkannya. ${ }^{23}$ Eksistensi maslahah dalam bangunan Syariah Islam memang tidak bisa dinafikan karena almaslahah (المصلحة) dan al-Syarî́ah (الثريعة) telah bersenyawa dan menyatu, sehingga kehadiran al-maslahah meniscayakan adanya tuntutan al-Syarî́ah (الثريعة).

Penelitian yang mendalam atas sedemikian banyak nass al-Qur'an dan Hadis memang menghasilkan kesimpulan yang meyakinkan bahwa hukumhukum Syariah senantiasa dilekati hikmah dan 'illah yang bermuara kepada

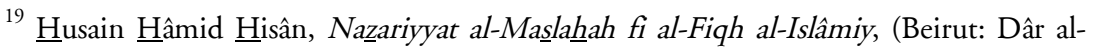
Nahdah al-'Arabiyyah, 1971), h.607.

${ }^{20}$ Lihat Mannâc al-Qattân, Raf al-Haraj fi al-Syarî́at al-Islâmiyyah, (Riyad: al-Dâr alSu'ûdiyyah, 1402 H/1982 M), h.61-62.

${ }^{21}$ Sa'îd Ramadân al-Bûtị, Dawâbit al-Maślahah fi al-Syarî̉ah al-Islâmiyyah, (Beirut: Mu'assasat al-Risâlah wa al-Dâr al-Muttahidah, 1421 H/2000 M), h.69

${ }^{22}$ Ibn al-Qayyim al-Jauziyyah, I'lâm al-Muwaqqi' în 'an Rabb al-'Âlamîn, (Kairo: Dâr alHadîts, 1425 H/2004 M), Juz ke-3, h.5.

${ }^{23}$ Husain Hâamid Hisân, Fiqh al-Maslahah wa Tatbîqâtuhu al-Mu âsirah, hlm. 4, dalam Seminar Internasional Tatanan Fundamental Ekonomi Islam Kontemporer, (Jeddah: IRTIIslamic Development Bank, Ramâdan, 1413 H), hlm. 4. (tidak diterbitkan). 
maslahah. ${ }^{24}$ Bahkan, hukum-hukum dimaksud bukan saja di bidang muamalat umum (non-ibadah mahdah), tetapi juga ibadah mahdah. Jadi, semua bidang hukum dengan aneka norma hukum yang telah digariskan oleh al-Qur'an dan Hadis berhulu dari, sekaligus bermuara kepada, maslahah bagi kehidupan umat manusia. Hal ini karena Allah tidak butuh kepada sesuatupun, sekalipun itu ibadah mahdah. Tegasnya, manusialah-sebagai hamba Allah-yang diuntungkan dengan adanya kenyataan bahwa maslahah menjadi alas tumpu hukum-hukum Syariah itu. ${ }^{25}$ Hadirnya hikmah dan "illah dalam norma hukum Allah (baik berupa al-amr maupun al-nahy) itu pada gilirannya menjamin eksisnya maslahah. Pada sisi lain, formulasi sejumlah legal maxim (al-qawa id alsyariyyah) bertumpu pada penemuan hikmah dan 'illah yang nota bene menjadi garansi eksisnya masslahah. Dengan demikian, masslahah merupakan poros dan titik beranjak bagi formulasi al-ahkâm al-syariyyah dan al-qawa id alsyar'iyyah. ${ }^{26}$

Mewujudkan maslahah merupakan elan vital Syariah Islam. Dalam setiap aturan hukumnya, al-Syârí mentransmisikan maslahah sehingga lahir kebaikan/kemanfaatan dan terhindar keburukan/kerusakan, yang pada gilirannya terealisasinya kemakmuran dan kesejahteraan di muka bumi dan

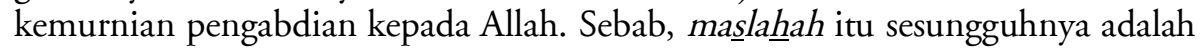
memelihara dan memperhatikan tujuan-tujuan Syara' berupa kebaikan dan kemanfaatan yang dikehendaki oleh Syara', bukan oleh hawa nafsu manusia. ${ }^{27}$ Norma hukum yang dikandung teks-teks Syariah (nussûs al-syarî́ah) pasti dapat mewujudkan maslahah, sehingga tidak ada maslahah di luar petunjuk teks Syariah; dan karena itu, tidaklah valid pemikiran yang menyatakan maslahah harus diprioritaskan bila berlawanan dengan teks Syariah. ${ }^{28}$ Maka, maslah $\underline{\text { ah }}$ pada hakikatnya ialah sumbu peredaran dan perubahan hukum Islam, di mana interpretasi atas teks Syariah dapat bertumpu padanya. ${ }^{29}$

Mohammad Hashim Kamali menyimpulkan bahwa identifikasi maslahah-sebagai inti maqâsidid al-syarî́ah-dapat didasarkan pada: (1) nusûs alsyarî́ah, terutama al-amr dan al-nahy, (2) 'illah dan hikmah yang dikandung nusûus al-syarî́ah, dan (3) istiqrâ. Identifikasi maslahah melalui pembacaan nusûs al-syarî́ah, terutama al-amr dan al-nahy dianut oleh ulama teoritisi hukum Islam Mazhab Zâhiri-kaum tektualis dalam aliran pemikiran hukum Islam. Sedangkan identifikasi maslahah melalui elaborasi 'illah dan hikmah

${ }^{24}$ Tâhir ibn 'Âsyûr, Maqâsid al-Syarî‘ah al-Islâmiyyah, (Tunis: Dâr Suhnun, Kairo: Dar al-Salâm, 1427 H/2006 M), h.12.

${ }^{25}$ Yûsuf al-Qaradâwi, Madkhal li Dirâsat al-Syarî́ah al-Islâmiyyah, (Kairo: Maktabah Wahbah, $1421 \mathrm{H} / 2001 \mathrm{M})$, h.58.

26 'Allâl al-Fâsiy, Maqâsid al-Syarî‘ah al-Islâmiyyah wa Makârimuha, (Rabat: Maktabah al-Wihdah al-'Arabiyyah, t.thlm.), h.138.

${ }^{27}$ Jalâl al-Dîn 'Abd al-Rahmân, al-Masâlih al-Mursalah wa Makânatuha fi al-Tasyrî́, (t.tp: Matba'at al-Sa'âdah, 1403 H/1983 M), h.12 dan 13.

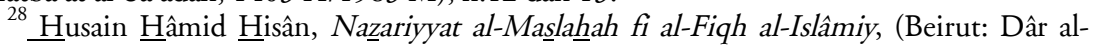
Nahdah al-'Arabiyyah, 1971), h.607. Lihat juga Syed Abul Hassan Najmee, Islamic Legal Theory and The Orientalists, (Lahore: Institute of Islamic Culture, 1989), h.94-96.

${ }^{29}$ Inilah yang disebut-oleh 'Ali Hasaballah-dengan Qiyâs al-Maślahahah. Lihat 'Aliy Hasaballah, Usûl al-Tasyrî’ al-Islâmiy, (Mesir: Dâr al-Ma ârif, 1383 H/1964 M), h.257. 


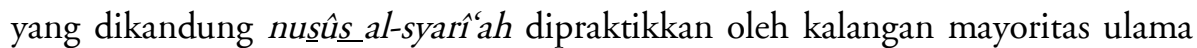
teoritisi hukum Islam. Sementara itu, identifikasi maslahah melalui pendekatan istiqrẩ merupakan tawaran genuine al-Syâtibi, meskipun al-Syâtibi sendiri tidak menafikan fungsi dua metode sebelumnya dalam upaya identifikasi maslahah. ${ }^{30}$

Sehubungan dengan relasi maslahah dan ijtihâd, di kalangan ulama dikenal istilah ijtihâd istislâhiy, yakni suatu upaya pengerahan segenap kemampuan untuk memperoleh hukum Syara' dengan cara menerapkan prinsip-prinsip hukum yang umum-universal terhadap suatu masalah/kasus yang tidak ditegaskan oleh nass Syara' yang spesifik dan Ijmâ ulama, yang pada intinya bermuara kepada mewujudkan maslahah (jalb al-maslahah) dan menghindari/menghilangkan mafsadah (daf $u$ al-mafsadah), yang sejalan dengan tuntutan prinsip-prinsip Syara'. Model ijtihâd ini sebenarnya mengarah pada memasukkan hukum kedalam medan cakupan nas $\underline{s}$ Syara' ${ }^{31}$ Menurut Ahmad Fathi Bahnasi, sebagian ulama ahli hukum Islam generasi al-tabi în berpaling dari aplikasi tekstual nass Syara' yang bersifat mutlak atau umum lantaran aplikasi tersebut berimplikasi tereliminasinya maslahah. Mereka justru menginterpretasi dan melakukan aplikasi nass Syara' itu dengan kerangka pikir maslahah meskipun memberikan kesan taqyî̀ atau takhsîs atau ihmâl terhadap nass. ${ }^{3 \overline{2}}$

Hukum-hukum Syariah itu dapat dibedakan menjadi 2 (dua) kategori: (1) hukum-hukum yang bersumber kepada al-Qur'an dan Sunnah secara langsung ${ }^{33}$, dan (2) hukum-hukum yang bersumber kepada ijtihâd, tanpa bersandar secara langsung kepada al-Qur'an dan Sunnah; dan yang terakhir inilah yang merupakan hukum-hukum yang dibentuk di atas fondasi maslahah. Akan tetapi, kedua kategori hukum itu sama-sama bertujuan merealisasi maślahah; dan sebagian maslahah itu berubah dan berkembang lantaran perubahan/perkembangan zaman dan faktor lainnya. Sudah menjadi pakem para ulama bahwa maslahah yang tidak ditegaskan oleh nass Syara ' terbuka kemungkinan untuk berubah dan berkembang; dan ini merupakan sesuatu yang rasional dan riil. $^{34}$

Menurut Ahmad Hassan, legislasi al-Qur'an itu mempertimbangkan tabiat dan kemampuan manusia serta kondisi sosial. Tujuan al-Qur'an dalam penetapan hukumnya-meskipun elemen hukum yang dituangkan dengan bahasa yang tegas sedikit jumlahnya-ialah maslahah. Al-Qur'an bertujuan

${ }^{30}$ Mohammad Hashim Kamali, The Dignity of Man: An Islamic Perspective, (Kuala Lumpur: Ilmiah Publisher, 2002), h.93

${ }^{31}$ Muhammad Sallâm Madkûr, al-Ijtihâad fi al-Tasyrî́ al-Islâmiy, (Kairo: Dâr al-Nahdah al-'Arabiyyah, $1404 \mathrm{H} / 1984 \mathrm{M})$, h.45.

${ }_{22}$ Mengenai deskripsi dan model aplikasi taqyîd, takhsîs, tarjîh $\underline{\underline{h}}$, dan yang semisalnya,

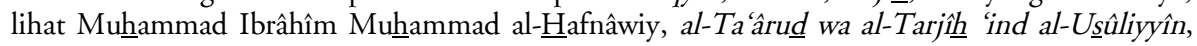
(t.tp.: Dâr al-Wafâ', 1408 H/1987 M)

${ }^{33}$ Lebih jauh mengenakan kedudukan Sunnah/Hadis sebagai sumber legislasi hukum Islam, lihat Mustafa Hasaniy al-Sibâ‘iy, al-Sunnah wa Makânatuhâ fi al-Tasyrî‘ al-Islâmiy, (Damaskus: al-Dâr al-Qaumiyyah, 1379 H/1960 M), h.343-352.

${ }^{34}$ Bustâmi Muhammad Sa'îd, Mafhûm Tajdîd al-Dîn, (Kuwait: Dâr al-Da’wah, 1405 H/1984 M), h.260-261. 
membentuk individu dan masyarakat yang ideal yang lebih berlandaskan kepada moralitas ketimbang hukum. Karena itulah, ia terkadang menjelaskan perintah-perintahnya melalui bahasa nalar dan tujuan, meskipun suatu otoritasabsolut sesungguhnya tidak perlu melakukan demikian. Inilah yang menjadi alasan mengapa genre dan nada legislasi al-Qur'an bersifat umum dan rasional sehingga ia dapat beradaptasi dengan kondisi-kondisi kehidupan yang terus berubah. $^{35}$

Menurut Mohammad Hashim Kamali, maslahah tidak diikat dengan pembatasan-pembatasan sebagaimana yang diberlakukan terhadap qiyâs dan istihhsân; ia meminta mujtahid berinisiatif menentukan ukuran-ukuran yang diperlukan, termasuk penetapan hukum kasus-kasus baru, dalam rangka mewujudkan sesuatu yang dipandang maslahah bagi masyarakat banyak. Lebih dari itu, maslahah yang bersifat umum (general), yang genuine, yang mendukung terwujudnya tujuan-tujuan Syariah Islam, dan yang tidak bertentangan dengan nass Syara', merupakan dasar, pijakan dan kerangka acuan yang valid bagi legislasi hukum Islam. ${ }^{36}$ Menurut Imran Ahsan Khan Nyazee, para ulama (ahli hukum Islam) bersepakat bahwa mas lahah dapat diaplikasikan sebagai alas dasar suatu ketetapan hukum, dan maslahah ini dapat dijadikan dasar pikiran ketika memperluas ketetapan hukum itu kepada kasus-kasus baru. Inilah yang merupakan basis doktrin maslahaha. ${ }^{37}$

Konsep mas lahahah-sebagai inti maqâssid al-syarî‘ah-merupakan alternatif terbaik untuk pengembangan metode-metode ijtihad, di mana al-Qur'an dan Sunnah harus dipahami melalui metode-metode ijtihad dengan memberi penekanan pada dimensi maslahah. ${ }^{38}$ Konsep maslahah merupakan wahana bagi perubahan hukum. Melalui konsep ini para ulama fikih memiliki kerangka kerja untuk menangani masalah hukum, yang inheren di dalam sistem hukum yang didasarkan kepada nass Syara' (al-Qur'an dan Hadis), yang nota bene mengandung fondasi materiil hukum yang terbatas mengenai urusan kehidupan dalam situasi lingkungan yang terus berubah. Dengan demikian, konsep maslahah memberi legitimasi bagi aturan hukum baru dan memungkinkan para ulama fikih mengelaborasi konteks masalah yang tidak ditegaskan oleh nass Syara'. Seberapa besar perubahan hukum dapat dicapai melalui aplikasi konsep maslahah tergantung pada, terutama, pola penalaran hukum berbobot maslahah yang diterapkan para ulama fikih. ${ }^{39}$

${ }^{35}$ Ahmad Hassan, Analogical Reasoning in Islamic Jurisprudence: A Study of the Juridical Principle of Qiyâs, (New Delhi: Adam Publishers and Distributors, 1994), h.153.

${ }^{36}$ Mohammad Hashim Kamali, "Fiqh and Adaptation to Social Reality" dalam Jurnal The Muslim World, 1996, Vol.86, No.1 h.72.

${ }^{37}$ Imran Ahsan Khan Nyazee, Theories of Islamic Law: The Methodology of Ijtihad, (New Delhi: Adam Publishers \& Distribution, 1996), h.236-237.

38 Asafri Jaya Bakri, Konsep Maqashid Syariah Menurut al-Syatibi, (Jakarta: RajaGrafindo Persada, 1996), h.168.

${ }^{39}$ Felicitas Opwis, "Maslaha in Contemporary Islamic Legal Theory ”, dalam Journal Islamic Law and Society, (Leiden: Koninklijke Brill NV, 2005), Vol. 12, No. 2, h.183. 


\section{Kategorisasi Maslahah}

Yusuf al-Qaradawi mengkonstatir bahwa substansi maslahah yang dikehendaki oleh Syariah Islam untuk ditegakkan dan dipelihara itu merupakan maslahah yang komprehensif, integral dan holistik, yang mencakup perpaduan maslahah dunyawiyyah dan maslahah ukhrawiyyah, maslahah maddiyyah dan maslahah rûhiyyah, maslahah fardiyyah dan maslahah mujtama iyyah, maslahah qaumiyyah khâsssah dan masslahah insâniyyah âmmah, maslahah hâdirah dan maslahah mustaqbalah. Atas dasar ini, Yusuf al-Qaradawi menegaskan bahwa konsep mas lahah yang menjiwai Syariat Islam, tidak bisa diidentikkan dengan utilitiarianisme dan pragmatisme, yang nota bene berhulu pada faham materialisme. ${ }^{40}$

Sementara itu, patut kiranya dipertanyakan bagaimanakah cara yang meyakinkan untuk mengetahui al-maqâssid al-syar'iyyah, baik dalam level kulliy maupun juz'iy? Menjawab hal ini, al-Syâtibi menggagas pemikiran bahwa almaqâssid al-syar'iyyah dapat diketahui dengan cara sebagai berikut. Pertama, memahami tujuan legislasi suatu hukum melalui logika kebahasaan dari bahasa Arab. Kedua, memahami, secara tekstual sekaligus secara kontekstual, al-amr dan al-nahy dari teks-teks Syariah. Ketiga, memahami tujuan-tujuan primer (almaqâsid al-aśliyyah) dan tujuan-tujuan sekunder (al-maqâsid al-tabaiiyyah). Kelima, menerapkan metode induksi (al-istiqrẩ). ${ }^{41}$

Sementara Yusuf al-Qaradawi mengajukan pandangan tentang cara yang meyakinkan untuk mengetahui al-maqâsid al-syar'iyyah tersebut. Pertama, meneliti setiap 'illah (baik mansûs sah maupun gair mansîs $\underline{s} a h)$ pada teks alQur'an dan Hadis. Misalnya QS. al- $\underline{\text { Hadîd}} / 57: 25$, ayat ini sesungguhnya mempromosikan keadilan sebagai tujuan seluruh doktrin agama samawi, di mana hal demikian merupakan simpulan dari adanya lâm ta lîl yang menyertai frase "li yaqûm al-nâs bi al-qist.." Hal yang sama juga terdapat pada QS. alHasyr/59:7 (li kai lâ yakûna dûlat-an bain al-agniyầi minkum), QS. alAnbiyâ'/21/107 (wa mâ arsalnâka illâ rahmat-an li al-âlamîn), dan alBaqarah/2:179 (wa la kum fi al-qisâsa i hayât-un yâ uli al-albâb). Kedua, mengkaji dan menganalisis hukum-hukum partikular, untuk kemudian menyimpulkan cita pikiran hasil pemaduan hukum-hukum partikular tersebut. ${ }^{42}$

${ }^{40}$ Yusuf al-Qaradawi, Madkhal li Dirâsat al-Syarî́ah al-Islâmiyyah, (Kairo: Maktabah Wahbah, 1990), h.62.

${ }^{41}$ Dalam kaitan ini, al-Syâtibi menguraikan mutiara pikirannya tentang teori maqâsid alsyarîah dalam bagian khusus yang diberi tajuk "Kitâb al-Maqâsid’". Lihat Abû Ishâq al-Syâtibi, al-Muwâfaqât fi Usûl al-Syarî́ah, , hlm. Jilid I, Juz ke-2, h.3-313. Bandingkan dengan Ahmad alRaisûniy, Nazariyyat al-Maqâsid 'ind al-Imâm al-Syâtíibi, (Beirut: al-Ma'had al-'Âlamiy li al-Fikr al-Islâmiy), h.295-314; dan Muhammad Khalid Masud, Islamic Legal Philosophy: A Study of Abû Ishaq al-Shâtibi's Life and Thought, (New Delhi: International Islamic Publishers, 1989), h.221-225; dan Tâhir ibn 'Âsyûr, Maqâsid al-Syarî́ah al-Islâmiyyah, (Tunis: Dâr Suhnun, Kairo: Dar al-Salâm, 1427 H/2006 M), h.16-20; dan Jamâl al-Dîn 'Atiyyah, Nahlwa Taf îl Maqâsid alSyarî́ah, (Damaskus: Dâr al-Fikr, 2001), h.15-27.

${ }^{42}$ Yusuf al-Qaradawi, Fiqih Maqashid Syariah: Moderasi Islam antara Aliran Tekstual dan Aliran Liberal, terj. Arif Munandar Riswanto, (Jakarta: Pustaka Al-Kautsar, 2007), h.23-25. 
Menurut pandangan al-Gazâli, berdasarkan segi ada tidaknya ketegasan justifikasi Syara' terhadapnya (syahâdat al-syar'î), maslahahah dibedakan menjadi tiga, yaitu (1) maslahah yang mendapat ketegasan justifikasi Syara' terhadap penerimaannya (maslahah mu'tabarah); (2) maslahah yang mendapat ketegasan

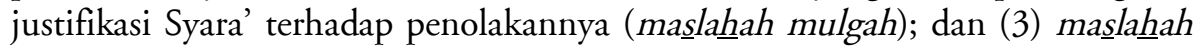
yang tidak mendapat ketegasan justifikasi Syara', baik terhadap penerimaannya maupun penolakannya (maslahah mursalah). ${ }^{43}$ Muhammad Muslehuddin melihat bahwa kategorisasi masslahah dengan trilogi maslahah mu'tabarahmaslahah mulgah- maslahah mursalah tetap harus mempertimbangkan dimensi kepentingan masyarakat dan realitas sosial yang terus berubah sehingga hukum Islam (Syariah) harus bergerak seiring sejalan dengan perubahan realitas sosial yang terjadi, yang pada gilirannya fleksibilitas hukum Islam (Syariah) dapat dipertahankan. ${ }^{44}$

Di sisi lain, al-Gazâli juga mengkategorisasi maslahahah berdasarkan segi kekuatan substansinya (quwwatiha fi dzâtiha), di mana masslahah itu dibedakan

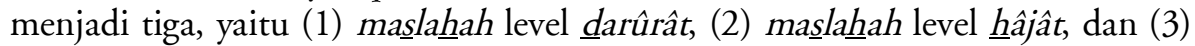
maslahah level tahsînat/tazyînat. Masing-masing bagian disertai oleh maślahah penyempurna/pelengkap (takmilah/tatimmah). Pemeliharaan lima tujuan/prinsip dasar (al-ușûl al-khamsah) yang berada pada level darûrât merupakan level terkuat dan tertinggi dari maslahah. Kelima tujuan/prinsip

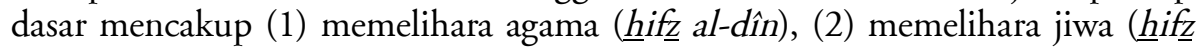
al-nafs), (3) memelihara akal pikiran (hifź al-'aql), (4) memelihara keturunan

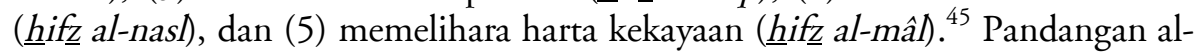
Gazâli tentang al-usûl al-khamsah ini disempurnakan lagi oleh Syihâb al-Dîn alQarafi (w. $684 \mathrm{H}$ ) dengan menambahkan satu tujuan/prinsip dasar lagi, yakni

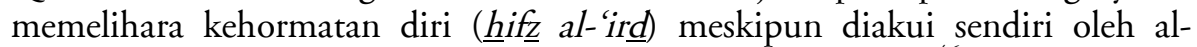
Qarafi bahwa hal ini menjadi bahan perdebatan para ulama. ${ }^{46}$ Pandangan ini nampaknya cukup berdasar lantaran adanya nass Syara' yang secara eksplisit melarang al-qadzf (tindakan melemparkan tuduhan palsu zina terhadap orang lain) dan sekaligus mengkriminalisasinya (Q.s. al-Nûr/24:4 dan 23).

Dalam pemikiran 'Izz al-Din ibn 'Abd al-Salâm (w. 660 H) maslahahah dibedakan menjadi tiga macam, yaitu (1) maslahah yang terkandung dalam urusan yang bersifat boleh/halal (masâlih al-mubâhât), (2) maslahahah yang terkandung dalam urusan yang bersifat sunnat (masâli $\underline{h}$ al-mandûbât), dan (3) maślahah yang terkandung dalam urusan yang bersifat wajib (masấlih alwâjibât). Sedangkan mafsadah dapat dibedakan menjadi dua macam, yaitu (1) mafsadah yang terkandung dalam urusan yang bersifat makruh (mafâsid al-

${ }^{43}$ Abu Hâmid Muhammad al-Gazâli, al-Mustaśfa min 'Ilm al-Uśûl, (Beirut: Mu'assasat al-Risâlah, 1417 H/1997 M), Juz ke-1, h.414.

${ }^{44}$ Muhammad Muslehuddin, Philosophy of Islamic Law and The Orientalists, (New Delhi: Markazi Maktaba Islami, 1985), h.160.

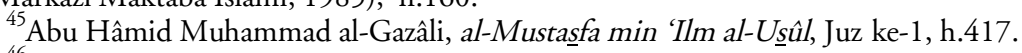

46 Syihâb al-Dîn al-Qarafi, Syarh Tanqîh al-Fușûl fi Ikhtisầr al-Mahsûul fi al-Usûul, (Mesir: al-Matba'ah al-Khairiyyah, $1307 \mathrm{H}$ ) sebagaimana dikutip dalam 'Abd al-'Azîz ibn 'Ábd al-Rahmân ibn 'Ali ibn Rabî'ah, 'Ilm Maqâsid al-Syârì', (Riyad: Maktabah al-Malik Fahd alWataniyyah, $1423 \mathrm{H} / 2002)$, h.63. 
makrûhât) dan (2) mafsadah yang terkandung dalam urusan yang bersifat haram (mafâsid al-muharramât). ${ }^{47}$

Lebih dari itu, al-'Izz ibn 'Abd al-Salâm memandang maslahah itu dapat dibedakan menjadi dua macam, yaitu (1) maslahah dalam arti denotatif (haqîqiy), yakni kesenangan dan kenikmatan, dan (2) maslahah dalam arti konotatif (majâziy), yakni media yang mengantarkan kepada kesenangan, kebaikan dan kenikmatan. Bisa saja terjadi bahwa media yang mengantarkan kepada maslahah itu berupa mafsadah, sehingga mafsadah ini diperintahkan atau dibolehkan, bukan lantaran statusnya sebagai mafsadah, tetapi sebagai sesuatu yang mengantarkan kepada maslahah. ${ }^{48}$

Abû Bakr Ismâî̂l Muhammad Mîqâ menandaskan bahwa dengan mengacu pada batasan maslahah, dapat dibedakan dua kategori maslahah. Pertama, maslahah 'ammâh, yakni maslahah yang pemeliharaannya menentukan kebaikan dan kesejahteraan segenap masyarakat atau sebagian besar masyarakat, tanpa melihat pada satuan-satuan individu dari mereka. Kedua, maslahah khâssah, yakni maslahah yang pemeliharaannya menentukan kebaikan dan kesejahteraan yang bersifat individuil; dari yang bersifat individuil ini akan mengarah kepada kebaikan dan kesejahteraan yang bersifat kolektif (publik). ${ }^{49}$

Dalam pemikiran Najm al-Dîn al-Tûfi maslahah dapat dibedakan menjadi dua macam, yaitu maslahah dalam arti 'urfi dan maslahah dalam arti syar'i. Menurut al-Tûfi yang disebut pertama ialah hal penyebab yang membawa kepada kebaikan dan kemanfaatan, seperti perniagaan yang merupakan penyebab yang membawa kepada keuntungan; sedang yang disebut terakhir ialah penyebab yang membawa kepada tujuan al-Syâri', baik yang menyangkut ibadah maupun muamalah. Di sisi lain, al-Tûfi membedakan maslahahh itu menjadi dua macam: (1) maslahah yang dikehendaki al-Syâri' untuk hak-Nya, seperti aneka ibadah mahdah, dan (2) masslahah yang dikehendaki al-Syâri' untuk kebaikan makhluk-Nya dan keteraturan hidup mereka, seperti aneka bentuk muamalah. ${ }^{50}$

Abû Ishâq al-Syâtibi mengkategorisasi maslahah menjadi 3 (tiga) macam, yaitu (1) darûriyyah, (2) hâajiyyah, dan (3) tahsîniyyah. Lebih jauh alSyâtibi menjelaskan bahwa darûriyyah ialah sesuatu yang tidak boleh tidak ada demi tegaknya kebaikan dan kesejahteraan, baik menyangkut urusan ukhrawi maupun urusan duniawi, di mana manakala ia lenyap, tidak ada, maka tidak dapat terwujud kehidupan duniawi yang tertib dan sejahtera; bahkan, yang terwujud ialah kehidupan duniawi yang chaos dan kehidupan ukhrawi yang

47 'Izz al-Din ibn 'Abd al-Salâm, Qawâ‘id al-Ahkâm fi Masâliḥ al-Anâm, (Beirut: Dâr alJail, 1400 H/1980 M), Juz ke-1, h.9.

48 'Izz al-Din ibn 'Abd al-Salâm, Qawâ'id al-Ahkâm fi Masâlih al-Anâm, Juz ke-1, h.14.

${ }^{49}$ Abû Bakr Ismấ̂ill Muhammad Mîqâ, al-Ra'yu wa Atsaruhu fi Madrasat al-Madînah: Dirâsah Manhajïyyah Tatbîqiyyah Tutsbitu Salâhiyyat al-Syarî́ah li Kulli Zamân wa Makân, (Beirut: Mu'assasat al-Risâlah, 1405 H/1985 M), h.338.

${ }^{50}$ Najm al-Dîn al-Tûfi, Syarh al-Arba'în al-Nawawiyyah, hlm. 19, sebagaimana dimuat sebagai lampiran dalam Mustafa Zaid, al-Maślahah fi al-Tasyrî̀ al-Islâmiy wa Najm al-Dîn alTûfi, (t.tp.: Dâr al-Fikr al-'Arabiy, 1384 H/1964 M), h.211. 
celaka dan menderita. Bagi al-Syâtíbi, darûriyyah itu mencakup upaya-upaya memelihara agama, memelihara jiwa, memelihara keturunan, memelihara harta kekayaan, dan memelihara akal budi. ${ }^{51}$

Adapun hâajiyyah, dalam pandangan al-Syâtibi, ialah sesuatu yang dibutuhkan dari sisi kemampuannya mendatangkan kelapangan dan menghilangkan kesempitan yang biasanya membawa kepada kesukaran dan kesusahpayahan yang diringi dengan luputnya tujuan/sasaran. Apabila hâajiyyah tidak diperhatikan maka akan muncul kesukaran dan kesusahpayahan, tetapi tidak sampai menimbulkan kerusakan yang biasanya terjadi pada maslahah darûriyyah, yang bersifat umum. Kategori hâjiiyyah sesungguhnya mengarah kepada penyempurnaan darûriyyah, di mana dengan tegaknya hâajiyyah, akan lenyap segala masyaqqah dan tercipta keseimbangan dan kewajaran, sehingga tidak menimbulkan ekstrimitas (ifrât wa tafrît $)$. $^{52}$

Sedangkan tahsinniyyah, menurut pendapat al-Syâtibi, ialah sesuatu yang berkenaan dengan memperhatikan kebiasaan-kebiasaan yang baik dan menghindari kebiasaan-kebiasaan yang buruk, berdasarkan pertimbangan akal sehat. Hal ini sering disebut dengan makârim al-akhlâq. Bagi al-Syâtibi, keberadaan tahsinniyyah bermuara kepada kebaikan-kebaikan yang melengkapi prinsip maślahahah darûriyyah dan maslahah hâjjiyyah; ini karena ketiadaan tahsinniyyah tidak merusak urusan darûriyyah dan hâjizyyah; ia hanya berkisar pada upaya mewujudkan keindahan, kenyamanan dan kesopanan dalam tata hubungan sang hamba dengan Tuhan dan dengan sesama makhluk-Nya. ${ }^{53}$

Dalam pada itu, Tâhir ibn 'Âsyûr berpendapat bahwa maslahah dapat dibedakan menjadi dua macam, yaitu maślahah 'ammâh dan maslahaha khâssah. Yang disebut pertama ialah sesuatu yang mengandung kebaikan/kemanfaatan bagi seluruh masyarakat atau mayoritas masyarakat, seperti pemeliharaan harta benda dari bahaya kebakaran dan tenggelam. Jenis mas lahah 'ammâh inilah yang merupakan perhatian sebagian besar legislasi al-Qur'an dan Sunnah. ${ }^{54}$

Husain Hâmid Hisân menyimpulkan bahwa maslahahah yang macam (nau')-nya atau genus (jins)-nya tidak diakui oleh nass syara' merupakan maslahah yang palsu, yang ditolak; hal ini merupakan kesepakatan para ulama. Seiring dengan itu, maslahah yang diyakini al-Tûfi tidak berbeda dengan macam (nau') maslahah yang palsu, yang ditolak tersebut; hanya ia lebih mengistimewakan dan mengutamakan mas lah $\underline{h} a h$ ini ketimbang nass Syara' dan Ijmấ ulama. ${ }^{55}$

${ }^{51}$ Abû Ishâaq Ibrâhîm al-Syâtibi, al-Muwâfaqât fi Usîul al-Syarî̉ah, (Beirut: Dar al-Kutub al-'Ilmiyyah, t.th.), Jilid I, Juz ke-2, h.7-13.

14.

${ }^{2}$ Abû Ishâa Ibrâhîm al-Syâtibibi, al-Muwâfaqât fi Usûul al-Syarî̉ah, Jilid I, Juz ke-2, h.9-

\footnotetext{
${ }^{53}$ Abû Ishâaq Ibrâhîm al-Syâtibibi, al-Muwâfaqât fi Usîul al-Syarî̉ah, Jilid I, Juz ke-2, h.910.

${ }^{54}$ Tâhir ibn 'Âsyûr, Maqâsid al-Syarî́ah al-Islâmiyyah, (Tunis: Dâr Suhnun, Kairo: Dar al-Salâm, 1427 H/2006 M), h.63.

55 Husain Hâmid Hisân, Nazariyyat al-Maslahahah fi al-Fiqh al-Islâmiy, (Beirut: Dâr alNahdah al-'Arabiyyah, 1971), h.608.
} 
'Abdullah Yahya al-Kamâli berpendapat bahwa dalam rangka pengembangan hukum Islam, harus dipahami 3 (tiga) model kategorisasi maslahah. Pertama, kategorisasi masslahah yang meliputi maslahah mu'tabarah, maslahah mulgah, dan maslahah mursalah. Kedua, kategorisasi maslahah yang

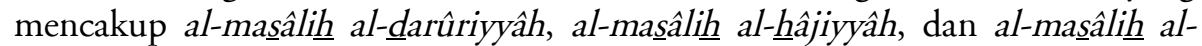
tahsîniyyah. Ketiga, kategorisasi maslahah yang terdiri atas maslahat al-dîn, maslahat al-nafs, maslahat al-'aql, maślahat al-nasl, dan maslahat al-mâl. ${ }^{56}$

\section{Relasi Maslahah dengan Nass Syara'}

Penting untuk dibedakan dua domain aplikasi maslahaha untuk legislasi hukum Islam. Pertama, kasus-kasus dan masalah-masalah yang dicakup oleh nass Syara' dan diberikan aturan hukum relatif rinci olehnya. Kedua, kasuskasus dan masalah-masalah yang tidak dicakup oleh nass Syara' yang spesifik dan tidak diatur secara rinci olehnya. Yang ramai dan gencar diwacanakan oleh para pakar hukum Islam ialah domain yang disebut pertama. Sedangkan domain kedua tetap diwacanakan oleh mereka, tetapi tidak seramai dan segencar yang pertama. ${ }^{57}$

Adagium bahwa Syariah Islam itu adalah Syariah maslahah, telah diterima oleh hampir segenap umat Islam, baik kalangan ulama maupun kalangan awam. Proposisi yang kerap dikemukakan mereka sehubungan dengan hal tersebut, antara lain, ialah: "Syariah Islam itu datang membawa misi realisasi maslahah dan eliminasi madarrah"; "Syariah Islam itu intinya mendatangkan kemanfaatan dan mencegah kerusakan"; "Syariah Islam itu datang membawa misi realisasi dan maksimalisasi maslahah serta misi eliminasi dan minimalisasi madarrah"; "Syariah Islam itu diciptakan (oleh Allah) untuk mewujudkan maślahah bagi hamba-hamba-Nya, baik di dunia maupun di akhirat kelak"; "Syariah Islam itu dibangun dan dilandaskan pada alas hikmah dan maslahah bagi umat manusia, ia sepenuhnya mengandung keadilan (al-'adâlah), kasih sayang (al-rahlmah), dan maslahah; dan "Di mana saja didapati maslahah, di situlah hukum Allah, dan di mana saja ada hukum Allah, di situlah didapati maslahah". ${ }^{58}$

Adagium bahwa maslahah itu adalah Syariah Islam ${ }^{59}$, termanifestasikan pada sejumlah teori dan legal maxim hukum Islam yang berhulu dari dan

\footnotetext{
${ }^{56}$ Lihat 'Abdullah Yahyya al-Kamâli, Maqâsid al-Syarî‘ ah fi Dau' Fiqh al-Muwâzanât,

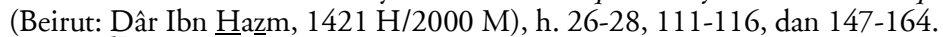

${ }^{57}$ Ahmad al-Raisûni, "al-Ijtihâd bain al-Nass, wa al-Maslahahah wa al-Wâqi' , h.29.

58 Lihat Muhammad Sa î̀d Ramadan al-Bûtí, Dawâbit al-Masląhah fi al-Syarî́ah alIslâmiyyah, (Beirut: al-Dâr al-Muttahidah dan Mu'assasat al-Risâlah, 1421 H/2000 M), h. 6, 8, 9, dan 13-22.

59 Adagium ini maksudnya bahwa di mana saja didapati maslahah, di situlah ada hukum Allahlm. Dalam kaitan ini pula al-Gazâli menyatakan: "Kadang kami menjadikan maslahah sebagai penanda hukum, dan kadang kami menjadikan hukum sebagai penanda maslahahlm." Lihat Aḥmad al-Raisûni dan Muhammad Jamâl Bârût, al-Ijtihâd : al-Naşs, wa al-Wầi ', wa alMaslahah, (Damaskus: Dâr al-Fikr, 1422 H/2002 M), h.32-33.
} 
bermuara kepada maslahahah. ${ }^{60}$ Sedangkan sebagai contoh legal maxim hukum Islam, yakni : (i) al-asl fi al-manâfi' al-hill wa fi al-madârr al-man'u, (ii) lâ darar

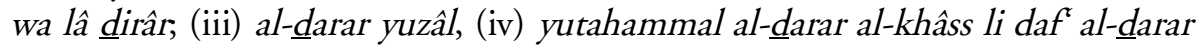
al-âmm, (v) al-darar al-asyadd yuzâl bi al-darar al-akhaff, (vi) tasarruf al-imâm 'ala al-ra iyyah manût bi al-maslahah. ${ }^{61}$

Tidak dapat dipungkiri bahwa Syariah Islam tidak memiliki tujuan kecuali realisasi maslahah bagi manusia. Semua nass dan aturan hukumnya hanya bertujuan realisasi maslahah sekaligus eliminasi mafsadah. Atas dasar ini, Aḥmad al-Raisûni mengajukan proposal model aplikasi maslahah dalam pengembangan hukum Islam. Menurut Ahmad al-Raisûni, merupakan suatu keharusan untuk merespon semua nass dan aturan hukum Syariah Islam dengan model pemahaman yang berorientasi maslahah (al-fahm al-maślahiy) dan model penerapan yang juga berorientasi mas lahah (al-tathî́q al-maslahiy). Inilah yang dinamakan respon yang berorientasi maslahah (al-ta'âmul almaślahiy ma'a al-nusûs), yang nota bene menyingkirkan respon yang mengasumsikan adanya kontradiksi nass dengan maslahah h, dan juga menggusur respon yang mengasumsikan nass yang nihil masslahaha, seperti yang diasumsikan oleh aliran literalis-skripturalistik-reduksionistik. ${ }^{62}$

Dalam pandangan Ahmad al-Raisûni, isu respons berorientasi maslahah terhadap nass Syara' meliputi: (1) kualifikasi maslahah dengan parameter nass Syara'; (2) interpretasi beorientasi maslahah terhadap nass (altafsîr al-maslahiy li al-nusûss); dan (3) aplikasi berorientasi maslahah terhadap

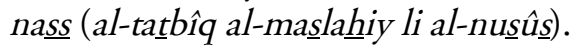

Mengenai isu kualifikasi maslahah dengan parameter nass Syara; Ahmad al-Raisûni menjelaskan bahwa semua nass Syara' bermuatan nilai-nilai 'adâlah, rahlmah, dan maslahah. (Perhatikan Q.s. al-Anbiyâ'/21:107). Maka dari itu, tiada sikap yang bisa dipegang melainkan memposisikan nass-nass Syara sebagai parameter untuk mengidentifikasi dan mengkualifikasi masslahah, membedakan (diferensiasi) maslahah dengan mafsadah, membedakan (diferensiasi) maslahah yang tinggi dengan maslahah yang rendah, serta membedakan masla $\underline{\underline{h}}$ hh yang esensial dengan maslah $\underline{\text { ah }}$ yang komplementer. ${ }^{63}$

Mengenai isu interpretasi berorientasi maslahah terhadap nass (al-tafsîr al-maslahiy li al-nusûsss), Ahmad al-Raisûni mengemukakan bahwa hal itu mengandung arti, yakni meneliti dan mengkaji tujuan-tujuan hukum (maslahah) yang menjiwai nass Syara', dan yang dikandung aturan-aturan hukumnya, untuk kemudian memahami nass Syara', mengeluarkan saripati makna dan pesannya yang sejalan dengan tujuan-tujuan hukum (mas $\underline{\text { lahaha) }}$ tersebut. Model interpretasi ini sesungguhnya tiada lain merupakan aplikasi dari

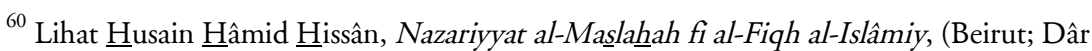
al-Nahdah al-'Arabiyyah, 1971), h.50, 220, 258, dan 322 .

${ }^{61}$ Lihat 'Abd al-Rahmân Ibrâhîm al-Kailani, Qawâid al-Maqâsid 'inda al-Imâm alSyâtibibi: 'Aradan wa Dirâsatan wa Tahlîlan, (Damaskus: Dâr al-Fikr, 2000), hlm. 84-87. Buku ini semula merupakan disertasi doktor 'Abd al-Rahmân Ibrâhîm al-Kailani, yang juga menjabat Guru Besar Ilmu Hukum Islam di Universitas Mu’tah, Yordania.

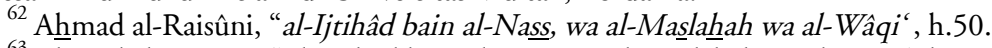

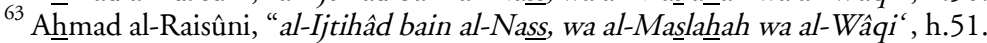


prinsip yang aksiomatik: "Syariah Islam sepenuhnya maslahah dan sepenuhnya rahmah (kasih sayang) ".64

Mengenai isu aplikasi berorientasi mas lahah terhadap nass, Ahmad alRaisûni menegaskan bahwa hal demikian merupakan derivasi dan pengembangan dari interpretasi berorientasi masslahah terhadap nass. Hal ini juga pada gilirannya mengeliminasi/menegasi prasangka kontradiksi antara nass Syara' dan maslahah. Aplikasi berorientasi masslahah terhadap nass mengandung arti, yakni memperhatikan tujuan hukum dan masla $\underline{\underline{h}}$ ah yang dikandung nass Syara ketika menerapkan ("membumikan") nass Syara" tersebut. Hal ini menuntut suatu pola "membumikan" nass Syara', suatu kerangka acuan yang menentukan kapan nass itu diterapkan dan kapan ia tidak diterapkan, serta kapan sesuatu itu dikecualikan dari cakupan nass itu. $^{65}$

\section{Penutup}

Dari uraian yang telah dipaparkan, dapat ditarik sejumlah pokok pikiran yang merupakan kesimpulan tulisan ini. Masla $\underline{h a h}$ merupakan tujuan yang dikehendaki oleh al-Syârí dalam hukum-hukum yang ditetapkan-Nya melalui teks-teks suci Syariah (nusûus al-syarî́ah) berupa al-Qur'an dan Hadis. Tujuan tersebut mencakup 6 (enam) hal pokok, yaitu perlindungan terhadap agama, perlindungan terhadap jiwa, perlindungan terhadap akal budi, perlindungan terhadap keturunan, perlindungan terhadap kehormatan diri, dan perlindungan terhadap harta kekayaan. Mas lahah itu bertingkat-tingkat, yakni darûriyyât, hâajiiyyât dan tahhsîniyyât. Sesuatu yang mampu menjamin eksistensi masing-masing dari keenam hal pokok itu merupakan maslahah pada tingkat darûriyyât. Sesuatu yang mampu memberi kemudahan dan dukungan bagi penjaminan eksistensi masing-masing dari keenam hal pokok itu merupakan masslahah pada tingkat hâajiyyât. Sesuatu yang mampu memberi keindahan, kesempurnaan, keoptimalan bagi penjaminan eksistensi masing-masing dari keenam hal pokok itu merupakan maslahah pada tingkat tahsîniyyât.

Maslahah itu mencakup 2 (dua) unsur yang padu dan holistik, yakni jalb al-manâfílal-masâalih wa dar' al-mafâsid/al-madârr yang mengandung arti "mewujudkan sesuatu yang bermanfaat/baik atau yang membawa kemanfaatan/kebaikan, dan mencegah serta menghilangkan sesuatu yang negatif-destruktif atau yang membawa kerusakan/mudarat, di mana hal ini semua tetap dalam kerangka arahan al-Qur'an dan Hadis. Dalam hal ini, perlu dipertimbangkan segi yang menyangkut kepentingan individual/terbatas (almaślahah al-khâssah) dan kepentingan umum/masyarakat luas (al-maslahah alâmmah), dan prioritas diberikan kepada kepentingan umum/masyarakat luas.

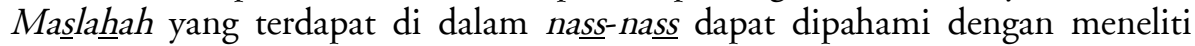
kandungan makna nass-nass itu. Di sini perlu diterapkan langkah "interpretasi berorientasi-maslahah terhadap nass" (al-tafsîr al-maslahiy li al-nusûus) dan

${ }^{64}$ Ah̆mad al-Raisûni, "al-Ijtihâd bain al-Nașs, wa al-Maślahah wa al-Wâqi", h.53.

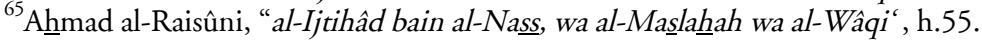




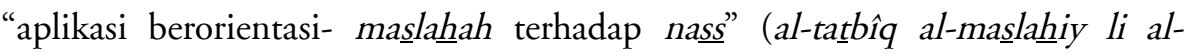
nușûs).

Dalam menghadapi kasus/masalah yang tidak ditentukan hukumnya secara eksplisit oleh nass yang spesifik, perlu merujuk kepada nass yang bersifat umum, diiringi dengan langkah "interpretasi berorientasi-maslahah terhadap nass" dan "aplikasi berorientasi-maslahah terhadap nass". Di samping itu, maslahah dapat ditemukan dan diaplikasikan: (1) melalui penerapan analisis jalb al-manâfi /al-masâliḥ wa dar' al-mafâsid/al-mad̂ârr, (2) melalui penerapan metode/dalil Syara' sekunder seperti al-qiyâs, al-maslahah al-mursalah, sadd aldzarî‘ah, dan al-'urf.; dan (3) melalui penerapan al-qawâiid al-fiqhiyyah (Islamic legal maxims). Dalam konteks ini, upaya mengkualifikasi sesuatu sebagai maślahah harus mengacu kepada parameter nass yang berupa garis-garis besar haluan nass sehingga terhindar dari kesimpulan hukum yang kontradiktif dengan nass.

\section{Pustaka Acuan}

'Abd al-'Azîz 'Âmir, al-Ta'zîr fi al-Syarî́ah al-Islâmiyyah, Beirut: Dâr al-Fikr al'Arabiy, t.th.

'Abd al-Wahhâb Khallâf, MasâAdir al-Tasyrî̀' al-Islâmiy fîmâ lâ Naśs fîh, Kuwait: Dâr al-Qalam, 1392 H/1972

Abû Bakr Ismâ'îl Muhammad Mîqâ, al-Ra'yu wa Atsaruhu fi Madrasat alMadînah: Dirâsah Manhajiyyah Tatbî́qiyyah Tutsbitu Salâhiyyat alSyarî‘ah li Kulli Zamân wa Makân, Beirut: Mu’assasat al-Risâlah, 1405 $\mathrm{H} / 1985 \mathrm{M}$

Abû Ishhâq Ibrâhîm al-Syâtibi, al-Muwâfaqât fi Usûl al-Syarî̉ah, Beirut: Dar alKutub al-'Ilmiyyah, t.th., Jilid I, Juz ke-2

Abû Hâmid Muhammad al-Gazâli, al-Mustaśfa min 'Ilm al-Usûul, tahquîq wa ta'lîq Muhammad Sulaimân al-Asyqar, Beirut: Mu'assasat al-Risâlah, 1417 H/1997 M, Juz ke-1

'Abdullah Yahyya al-Kamâli, Maqâsidi al-Syarî‘ah fi Dau' Fiqh al-Muwâzanât, Beirut: Dâr Ibn Hazm, 1421 H/2000 M

'Abd al-'Azîz ibn 'Abd al-Rahmân ibn 'Ali ibn Rabî‘ah, 'Ilm Maqâsid alSyârí,Riyad: Maktabah al-Malik Fahd al-Wataniyyah, 1423 H/2002

'Abd al-Rahmân Ibrâhîm al-Kailani, Qawầid al-Maqâsid inda al-Imâm alSyâtíibi : 'Aradan wa Dirâsatan wa Tahlîlan, Damaskus: Dâr al-Fikr, 2000

'Allâl al-Fâsiy, Maqâsid al-Syarîah al-Islâmiyyah wa Makârimuha, Rabat: Maktabah al-Wihdah al-'Arabiyyah, t.th.

Asafri Jaya Bakri, Konsep Maqashid Syariah Menurut al-Syatibi, (\Jakarta: RajaGrafindo Persada, 1996

Ahmad al-Raisûniy, Nazariyyat al-Maqâsid 'ind al-Imâm al-Syâtíibi, Beirut: alMa'had al-'̂̂lamiy li al-Fikr al-Islâmiy

Ahmad al-Raisûni dan Muhammad Jamâl Bârût, al-Ijtihâd : al-Naşs, wa alWâqi', wa al-Maslahahah, Damaskus: Dâr al-Fikr, 1422 H/2002 M 
Ahmad Hassan, Analogical Reasoning in Islamic Jurisprudence: A Study of the Juridical Principle of Qiyâs, New Delhi: Adam Publishers and Distributors, 1994

Ahmed Hassan, The Early Development of Islamic Jurisprudence, New Delhi: Adam Publishers \& Distributors, 1994

Husain Hâmid Hissân, Nazariyyat al-Maslahah fi al-Fiqh al-Islâmiy, Beirut: Dâr al-Nahdah al-'Arabiyyah, 1971

Husain Hâmid Hisân, Fiqh al-Maslahah wa Tatbîqâtuhu al-Mu'âsirah, dalam

Seminar Internasional Tatanan Fundamental Ekonomi Islam Kontemporer, Jeddah: IRTI-Islamic Development Bank, Ramâdan, $1413 \mathrm{H}$. (tidak diterbitkan).

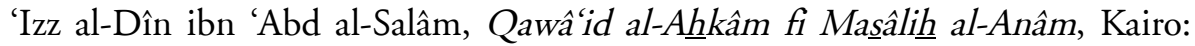
Maktabat al-Kulliyyât al-Azhariyyah, 1994, Juz ke-1

Ibn al-Qayyim al-Jauziyyah, I'lâm al-Muwaqqi în 'an Rabb al-Âlamîn, Kairo: Dâr al-Hadîts, 1425 H/2004 M, Juz ke-3

Imran Ahsan Khan Nyazee, Theories of Islamic Law: The Methodology of Ijtihad, New Delhi: Adam Publishers \& Distribution, 1996

Jalâl al-Dîn 'Abd al-Raḩmân, al-Masâliḥ al-Mursalah wa Makânatuhâ fi alTasyrî‘ al-Islâmiy, Kairo: Dâr al-Kitâb al-Jâmi'iy, 1403 H/1983 M

Mohammad Hashim Kamali, "Fiqh and Adaptation to Social Reality " dalam Jurnal The Muslim World, 1996, Vol.86, No.1

Mohammad Hashim Kamali, An Introduction to Sharî‘ah, Kuala Lumpur: ILMIAH Publishers, 2006

Muhammad Sa îd Ramadân al-Bûtí, Dawâbit al-Maslahahah fi al-Syarî́ah alIslâmiyyah, Beirut: Mu'assasat al-Risâlah, 1421 H/2000 M

Muhammad Kamâl al-Dîn Imâm, Nazariyyat al-Fiqh fi al-Islâm: Madkhal Manhajiy, Beirut: al-Mu'assasah al-Jâmi 'iyyah li al-Dirâsât wa al-Nasyr wa al-Tauzî‘, 1418 H/1998 M

Muhammad Khalid Masud, Islamic Legal Philosophy: A Study of Abû Ishaq alShâtibi's Life and Thought, New Delhi: International Islamic Publishers, 1989

Muhammad Muslehuddin, Philosophy of Islamic Law and The Orientalists, New Delhi: Markazi Maktaba Islami, 1985

Mustafa Zaid, al-Maślahah fi al-Tasyrî̀ al-Islâmiy wa Najm al-Dîn al-Tûfi, t.tp.: Dâr al-Fikr al-'Arabiy, 1384 H/1964 M

Mustafa Dîb al-Bugâ, Atsar al-Adillah al-Mukhtalaf fîhâ au Masâdir al-Tasyrî́ al-Tabaiyyah fi al-Fiqh al-Islâmiy, Damaskus: Dâr al-Imâm al-Bukhâri, t.th.

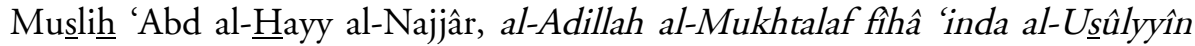
wa Tatbîqâtuhâ al-Mu'âsirah, Riyad: Maktabah al-Rusyd, $1424 \mathrm{H}$

Syed Abul Hassan Najmee, Islamic Legal Theory and The Orientalists, Lahore: Institute of Islamic Culture, 1989

Tâhir ibn 'Âsyûr, Maqâsid al-Syarî‘ah al-Islâmiyyah, Tunis: Dâr Suhnun, Kairo: Dar al-Salâm, 1427 H/2006 M 
328 - Asmawi; Konseptualisasi Teori Maslahah

Tâhâ Jâbir al-'Alwânî, Source Methodology in Islamic Jurisprudence (Usûul alFiqh al-Islâmî), Virginia: IIIT, 1415 H/1994

Yûsuf al-Qaradawi, Fiqih Maqashid Syariah: Moderasi Islam antara Aliran Tekstual dan Aliran Liberal, terj. Arif Munandar Riswanto, Jakarta: Pustaka Al-Kautsar, 2007

Yûsuf al-Qaradâwi, Madkhal li Dirâsat al-Syarî́ah al-Islâmiyyah, Kairo: Maktabah Wahbah, $1421 \mathrm{H} / 2001 \mathrm{M}$ 